\title{
KIT Exon 13 Mutation
}

National Cancer Institute

\section{Source}

National Cancer Institute. KIT Exon 13 Mutation. NCI Thesaurus. Code C104673.

A molecular genetic abnormality indicating the presence of a mutation in exon 13 of the

KIT gene located within 4q11-q12. 